\title{
Efficacy of botanical formulations and fungicides against Botryosphaeria dothidea, causing white rot in apple (Malus $\times$ domestica Borkh.)
}

\author{
Kishor Sharma* and Harender Raj \\ Department of Plant Pathology, Dr. Y. S. Parmar University of Horticulture and Forestry, Nauni, Solan-173230 \\ (H. P.), INDIA \\ *Corresponding author. E-mail: ks414173@gmail.com \\ Received: September 12, 2016; Revised received: March 5, 2017; Accepted: July 14, 2017
}

\begin{abstract}
The present study was conducted to determine inhibitory effect of plant extracts, their botanical formulations (BF1 and BF2) and safer fungicides against Botryosphaeria dothidea cause white rot of apple (Malus $\times$ domestica) during storage. Poisoned food technique was performed to evaluate the efficacy of different plant extracts, their botanical formulations and safer fungicides. Out of twelve botanicals evaluated under in vitro conditions against the white rot pathogen, leaf extract of Ocimum sanctum was found most effective among all the treatments with 54.07 per cent average inhibition in mycelial growth. Out of twelve plants evaluated for their efficacy, six effective plants Karu (Roylea elegans), Artemisia (Artemisia roxburghiana), Neem (Azadirachta indica), Bana (Vitex negundo), Tulsi (Ocimum sanctum) and Darek (Melia azedarach) were selected for making two botanical formulations (BF1 and BF2). While, BF1 was water based formulation and BF2 was cow urine based formulation. Among these botanical formulations, BF2 inhibited mycelial growth of white rot pathogen by 72.70 per cent and BF1 66.37 per cent at 100 $\%$ concentration. Whereas, among the tested fungicides, Score at $100 \mathrm{ppm}$ concentration was found to be most effective with $75.01 \%$ average inhibition in mycelial growth of the white rot pathogen.
\end{abstract}

Keywords: Apple, Botanical formulation, Cow urine, Plant extracts, White rot

\section{INTRODUCTION}

Apple (Malus $\times$ domestica Borkh.) belongs to family Rosaceae and it is the most important fruit crop grown extensively in temperate regions all over the world. In India, apple is grown in an area of about 3,13,000 hectare with total annual production of $24,98,000$ metric tonnes and national productivity of apple is 8.0 metric tonnes per hectare. Himachal is having an area of 1 , 07,700 ha with total annual apple production of 7 , $38,700 \mathrm{MT}$ and productivity of the state is $6.9 \mathrm{MT} / \mathrm{ha}$ (NHB, 2014). In India, commercial cultivation of apple is done in the states of Jammu and Kashmir, Himachal Pradesh, Uttrakhand and Arunachal Pradesh. Himachal Pradesh is situated in the heart of western Himalayas. The area and production under apple cultivation in this state has increased during last few decades, but the productivity per unit area has not increased proportionally. There are number of diseases which infect apple resulting in huge loss in yield. Among diseases, postharvest diseases are also important which result in significant economic losses. Post-harvest losses cause serious dents in the fruits industry of India as the average losses are to the tune of 30 per cent of the total yield which are valued approximately Rs 2 trillion annually. In apple, post-harvest losses ranges from 10 to 25 per cent. In Himachal Pradesh, fungal pathogens are dominant cause of these losses. The major post- harvest pathogens of pome fruits are Penicillium expansum, Botrytis cinerea, Monilinia fructigena and other common fungal species isolated from rotten pome fruits are Colletotrichum, Mucor, Rhizopus, Alternaria, Botryosphaeria, Fusarium and Neofabraea (Konstantinou, 2011 and Snowden, 1990). In Himachal Pradesh, Kaul (1979) reported 21 pathogens to cause post-harvest fungal rots and decays in apple fruits. Among different fungal post-harvest rots in apple, white rot caused by Botryosphaeria dothidea is one of important disease and this pathogen also cause canker on the stems. Putterill (1919) reported fruit rot and canker of apple caused by Botryosphaeria mali first time from South Africa. Later, Fulkerson (1960) also observed white rot as a major pre-harvest and post -harvest problem of apple in warm and wet weather conditions during summer. Moreover, management of post-harvest rots is a tedious task in apple as use of chemicals results in accumulation of residues on the fruits. Residues of chemicals on the surface of fruits results in adverse effects on the health of consumers. Thus, there is need for some alternative non-chemical methods like use of botanicals and other bio-pesticides like cow urine for the management of post-harvest diseases in apple. On the other hand, bio-chemicals derived from extracts of the plants have no toxic effects and their use is gaining popularity as alternatives 
to the hazardous chemical control measures. Cow urine from the very old period has been used singly or in combination with plants is shown to inhibit large number of phytopathogens including fungi and bacteria (Basak et al., 2002; Chauhan, 2004; Akhter et al., 2006 and Murugan et al; 2012). Thus, the present study was conducted to evaluate the comparative efficacy of cow urine and aqueous based plant extracts against mycelial growth of $B$. dothidea as well as their curative potential against white rot disease of apple.

\section{MATERIALS AND METHODS}

Isolation of pathogen: Isolations of the pathogen involved in the rot were made from diseased portion of fruit samples of apple collected from different marketing yards of Himachal Pradesh. The diseased fruits were initially surface sterilized with absolute alcohol under aseptic conditions. Small bits of 1 to $2 \mathrm{~mm}$ size were taken from juncture of diseased and healthy part of fruit with the help of sterilized sharp blade or scalpel. These bits were surface sterilized with mercuric chloride $(0.1 \%)$ for 10 to 20 seconds and washed thrice with sterilized distilled water under aseptic conditions. The bits were then placed on the sterilized filter paper to remove the excess moisture and subsequently transferred to sterilized Petri plates containing potato dextrose agar (PDA) medium. The medium was supplemented with streptocycline (100 ppm) while pouring in Petri plates after sterilization to restrict the bacterial contaminates. The inoculated Petri plates were incubated at $25 \pm 1^{0} \mathrm{C}$ in BOD incubator and examined daily for mycelial growth. The fungal growth developed in Petri plates was further purified by hyphal tip technique and was cultured on slants containing PDA. Pure culture was obtained by sub-culturing three times and maintained on culture slants in the refrigerator until required.

Identification of pathogen: The morphological characters of the isolated fungus were similar to the published description of the fungus given in "Compendium of Apple and Pear Diseases" given by Jones and Jones and Aldwinckle (1990). Thus, the description indicated the presence of Botryosphaeria dothidea. In addition, the pure culture of this particular pathogen got identified through National Centre of Fungal Taxonomy, New Delhi under Id. No. 5217.12, which identified it as $B$. dothidea.

Collection of plant materials: Fresh plant/plant parts (leaves and seeds) were collected locally from Herbal Garden of the University and nearby forest. The plant parts used for the present study are documented in Table 1.

Preparation of the plant extract: About 2 month old, freshly harvested $(200 \mathrm{~g})$ leaves of each plant except for neem and darek where 200 gram mature seed were taken and then washed under tap water. Each sample was grinded in mixer and blender by adding small quantity of sterilized distilled water. After grinding, $200 \mathrm{ml}$ distilled water was added and homogenized in orbital shaker at $2000 \mathrm{rpm}$ for half an hour to get 100 per cent extract of each plant. The plant material was then filtered through double-layered muslin cloth. Sterilization of the extract of different plants was done in autoclave at $1.05 \mathrm{~kg} / \mathrm{cm}^{2}$ pressure for 5 minutes and then the extracts were kept in refrigerator for further use.

In vitro efficacy of botanicals against the white rot pathogen: Water extract of leaves in case of Karu (Roylea elegans), Artemisia (Artemisia roxburghiana), Neem (Azadirachta indica), Bana (Vitex negundo), Mehandu (Dodonaea viscosa ), Bougainvillea (Bougainvillea glabra), Tulsi(Ocimum sanctum), Pudina (Mentha piperita), Safeda (Eucalyptus globules), Aloe (Aloe vera), seed extract in case of Darek (Melia azedarach), Neem (Azadirachta indica) and cow urine were evaluated at under in vitro condition at 10,25 and 50 per cent concentrations against white rot pathogen by poisoned food technique (Falck, 1907) to observe the inhibitory effect of these extracts on mycelial growth of $B$. dothidea. Per cent growth inhibition was calculated by using formula (Vincent, 1947).

$\mathrm{I}=\mathrm{C}-\mathrm{T} \mathrm{C}$

Where,

$\mathrm{I}=$ Inhibition (\%)

$\mathrm{C}=$ Diametric mycelial growth in control (mm)

$\mathrm{T}=$ Diametric mycelial growth in treatment $(\mathrm{mm})$

Preparation of the botanical formulations (BF1 and BF2): Out of twelve plants evaluated for their in vitro efficacy in inhibiting the growth of white rot pathogen, six effective plants were selected for making two botanical formulations. Six effective plants include Karu (Roylea elegans), Artemisia (Artemisia roxburghiana), Neem (Azadirachta indica), Bana (Vitex negundo), and Tulsi (Ocimum sanctum). In Botanical Formulation (BF1), equal quantity (200 g) of sixty days old freshly harvested leaves of Karu (Roylea elegans), Artemisia (Artemisia roxburghiana), Neem (Azadirachta indica), Bana (Vitex negundo), Tulsi (Ocimum sanctum) and $200 \mathrm{~g}$ of mature seeds of Darek (Melia azedarach) were taken. These leaves and seeds were washed in the running tap water and then with distilled water. Then, the paste of all these ingredients was made in a mixer and grinder. Then, equal quantity of distilled water $(200 \times 6=1200 \mathrm{ml})$ was added to this paste of leaves and seeds of six plants on weight and volume basis (w/ v). In Botanical Formulation 2 (BF2), equal quantity (200 g) of sixty days old freshly harvested leaves of Karu (Roylea elegans), Artemisia (Artemisia roxburghiana), Neem (Azadirachta indica), Bana (Vitex negundo), Tulsi (Ocimum sanctum) and $200 \mathrm{~g}$ of mature seeds of Darek (Melia azedarach) were taken. These leaves and seeds were washed in the running tap water and then with distilled water. Then, the paste of all these ingredients was made in mixer grinder by 
Kishor Sharma and Harender Raj / J. Appl. \& Nat. Sci. 9 (3): 1434 - 1439 (2017)

Table 1. Characteristics name, family and plant parts used for crude extract preparation.

\begin{tabular}{|c|c|c|c|c|}
\hline $\begin{array}{l}\text { Name of the } \\
\text { Plant }\end{array}$ & $\begin{array}{l}\text { Vernacular } \\
\text { name }\end{array}$ & Family & Habit & Part used \\
\hline $\begin{array}{l}\text { Melia azeda- } \\
\text { rach }\end{array}$ & Darek & Meliaceae & Perennial Tree & Seed \\
\hline Roylea elegans & Karu & Lamiaceae & Flowering plant & Leaf \\
\hline $\begin{array}{l}\text { Artemisia rox- } \\
\text { burghiana }\end{array}$ & Artemisia & Asteraceae & Herbaceous perennial plant & Leaf \\
\hline $\begin{array}{l}\text { Azadirachta } \\
\text { indica }\end{array}$ & Neem & Meliaceae & Perennial Tree & Seed, Leaf \\
\hline Vitex negundo & Bana & Lamiaceae & Aromatic shrub & Leaf \\
\hline $\begin{array}{l}\text { Dodonaea vis- } \\
\text { cosa }\end{array}$ & Mehandu & Sapindaceae & Shrub & Leaf \\
\hline $\begin{array}{l}\text { Bougainvillea } \\
\text { glabra }\end{array}$ & Bougainvillea & Nyctaginaceae & Evergreen, climbing shrub & Leaf \\
\hline Mentha piperita & Pudina & Lamiaceae & Herbaceous rhizomatous perennial plant & eaf \\
\hline $\begin{array}{l}\text { Ocimum sanc- } \\
\text { tum }\end{array}$ & Tulsi & Lamiaceae & Aromatic plant & Leaf \\
\hline $\begin{array}{l}\text { Eucalyptus } \\
\text { globulus }\end{array}$ & Safeda & Myrtaceae & Evergreen tree & Leaf \\
\hline $\begin{array}{l}\text { Aloe } \\
\text { vera }\end{array}$ & Ghrit Kumari & Xanthorrhoeaceae & Succulent plant & Leaf \\
\hline
\end{tabular}

Table 2. In vitro efficacy of twelve botanicals against the white rot pathogen (Botryosphaeria dothidea).

\begin{tabular}{lcccc}
\hline Botanicals & \multicolumn{4}{c}{ Per cent inhibition in mycelial growth at concentration (\%) } \\
& $\mathbf{1 0} \%$ & $\mathbf{2 5 \%}$ & $\mathbf{5 0} \%$ & Mean \\
\hline Melia azedarach & $11.94(20.19)$ & $38.60(38.39)$ & $44.16(41.63)$ & $31.56(33.41)$ \\
Roylea elegans & $21.66(27.71)$ & $27.49(31.61)$ & $42.22(40.51)$ & $30.46(33.27)$ \\
Artemisia roxburghiana & $28.33(32.13)$ & $38.61(38.39)$ & $49.72(44.82)$ & $38.88(38.45)$ \\
Azadirachta indica $(\mathrm{L})$ & $41.39(40.02)$ & $49.17(44.50)$ & $56.39(48.65)$ & $48.98(44.39)$ \\
Vitex negundo & $18.06(25.12)$ & $26.94(31.25)$ & $42.22(40.51)$ & $29.07(32.29)$ \\
Dodonaea viscosa & $6.39(14.56)$ & $9.72(18.13)$ & $16.38(23.82)$ & $10.83(18.84)$ \\
Bougainvillea glabra & $12.22(20.44)$ & $16.94(24.28)$ & $47.50(43.55)$ & $25.55(29.42)$ \\
Mentha piperita & $5.00(12.89)$ & $6.95(15.24)$ & $11.39(19.69)$ & $7.78(15.95)$ \\
Ocimum sanctum & $39.72(39.05)$ & $59.44(50.43)$ & $63.05(52.55)$ & $54.07(47.34)$ \\
Eucalyptus globules & $19.16(25.94)$ & $21.66(27.71)$ & $25.55(30.34)$ & $22.13(27.99)$ \\
Aloe vera & $18.89(25.73)$ & $20.83(27.14)$ & $24.72(29.80)$ & $21.48(27.56)$ \\
Azadirachta indica $(\mathrm{S})$ & $9.16(17.54)$ & $16.39(23.85)$ & $36.66(37.24)$ & $20.74(26.21)$ \\
Cow urine & $5.55(13.59)$ & $8.61(17.04)$ & $45.11(42.17)$ & $19.76(24.27)$ \\
Control & $0.00(0.00)$ & $0.00(0.00)$ & $0.00(0.00)$ & $0.00(0.00)$ \\
Mean & $16.96(22.49)^{\mathrm{c}}$ & $24.38(27.71)^{\mathrm{b}}$ & $36.08(35.38)^{\mathrm{a}}$ & \\
\hline
\end{tabular}

S, Seeds; L, Leaves Extract, *Figures in parentheses are arc sine transformed values, *Figures denoted by same letter do not differ significantly, $\mathrm{CD}_{(0.05)}$, Botanical (0.39), Concentration (0.85), Botanical x Concentration (1.48)

Table 3. In vitro efficacy of fungicides against white rot pathogen (B. dothidea).

\begin{tabular}{lcccc}
\hline Fungicide & \multicolumn{3}{c}{ Per cent inhibition in mycelial growth at concentration (ppm) } \\
& $\mathbf{2 5}$ & $\mathbf{5 0}$ & $\mathbf{1 0 0}$ & Mean \\
\hline Score 25 EC (difenoconazole) & $58.71(49.99)$ & $77.09(61.38)$ & $89.25(70.84)$ & $75.01(60.73)$ \\
Amistar 25 EC (azoxystrobin) & $48.89(44.35)$ & $58.15(49.67)$ & $72.96(58.64)$ & $60.00(50.89)$ \\
Folicur 250 EC (tebuconazole) & $55.10(47.91)$ & $73.66(59.10)$ & $86.29(68.24)$ & $71.68(58.42)$ \\
Insignia 20 WG (pyraclostrobin) & $35.52(36.56)$ & $46.6(43.03)$ & $56.59(48.76)$ & $46.23(42.78)$ \\
Flint 50 WG (trifloxystrobin) & $49.26(44.56)$ & $54.06(47.31)$ & $77.04(61.35)$ & $60.12(51.07)$ \\
Ergon 44.3\% w/w SC & $34.81(36.14)$ & $52.59(46.47)$ & $75.55(60.34)$ & $54.32(47.65)$ \\
(kresoxim-methyl) & $0.00(0.00)$ & $0.00(0.00)$ & $0.00(0.00)$ & $0.00(0.00)$ \\
Control & $47.04(43.25)^{\mathrm{c}}$ & $60.35(51.16)^{\mathrm{b}}$ & $76.28(61.36)^{\mathrm{a}}$ & \\
Mean & & & \\
\hline
\end{tabular}

*Figures in parentheses are arc sine transformed values, *Figures denoted by same letter do not differ significantly, $\mathrm{CD}_{(0.05)}$ 
Kishor Sharma and Harender Raj / J. Appl. \& Nat. Sci. 9 (3): 1434 - 1439 (2017)

Table 4. In vitro evaluation of fungicide and botanical formulations (BF1 and BF2).

\begin{tabular}{lccccc}
\hline Treatments & \multicolumn{5}{c}{ Per cent inhibition in mycelial growth at concentration ( \% ) } \\
\cline { 2 - 6 } & $\mathbf{1 0} \%$ & $\mathbf{2 5 \%}$ & $\mathbf{5 0} \%$ & $\mathbf{1 0 0} \%$ & Mean \\
\hline BF1 & $14.59(22.43)$ & $34.04(35.66)$ & $57.37(49.21)$ & $66.37(54.53)$ & $43.09(40.46)$ \\
BF2 & $17.23(24.5)$ & $39.26(38.78)$ & $64.33(53.30)$ & $72.70(58.48)$ & $48.38(43.77)$ \\
Fungicide (Score)* & $33.44(35.31)$ & $58.71(49.99)$ & $77.09(61.38)$ & $89.25(70.84)$ & $64.63(54.38)$ \\
Control & $0.00(0.00)$ & $0.00(0.00)$ & $0.00(0.00)$ & $0.00(0.00)$ & $0.00(0.00)$ \\
Mean & $21.76(27.41)$ & $44.00(41.48)$ & $66.26(54.63)$ & $76.11(61.28)$ & \\
\hline
\end{tabular}

*Score was tested at 10,25,50 and100 ppm, *Figures in parentheses are arc sine transformed values, Effect CD 0.05 , Treatments 0.79 , Concentration 0.91 , Treatment $\times$ concentration 1.57

adding little quantity of fresh cow urine of Jersey cow. Then, equal quantity of cow urine $(200 \times 6=1200 \mathrm{ml})$ was added to this paste of leaves and seeds of six plants on weight and volume basis (w/v). Thus, while $\mathrm{BF} 1$ is water based formulation, BF2 is cow urine based formulation. These formulations were sterilized at $1.05 \mathrm{~kg} / \mathrm{cm}^{2}$ for 5 minutes and stored in air tight bottles in refrigerator for further studies.

In vitro evaluation of different fungicides against the white rot pathogen (Botryosphaeria dothidea): The efficacy of six fungicides viz. kresoxim-methyl (Ergon 44.3\% w/w SC), difenoconazole (Score 25 EC), tebuconazole (Folicur 25 EC), azoxystrobin (Amistar $25 \mathrm{EC}$ ), trifloxystrobin (Flint $50 \mathrm{WG}$ ), pyraclostrobin (Insignia $20 \mathrm{WG}$ ) was tested under in vitro conditions against the white rot pathogen (Botryosphaeria dothidea) at 25, 50 and 100 ppm concentrations by poisoned food technique. Per cent growth inhibition was calculated by using formula (Vincent, 1947).

In vitro evaluation of botanical formulations (BF1 and BF2): However, BF1 is water based formulation and BF2 is cow urine based formulation. These formulations were sterilized at $1.05 \mathrm{~kg} / \mathrm{cm}^{2}$ for 5 minutes and were evaluated at different concentrations $(10,25,50$ and $100 \%$ ) respectively, against effective fungicide (Score) to compare their mycelium inhibiting properties for the white rot pathogen by poisoned food technique. Per cent growth inhibition was calculated by using formula (Vincent, 1947).

\section{RESULTS AND DISCUSSION}

All the twelve plant extracts and cow urine were found effective in inhibiting the growth of $B$. dothidea over control. However, data presented in table 2 indicated that among different treatments, O. sanctum $(50 \%)$ leaf extract was found most effective with $63.05 \%$ average inhibition of pathogen followed by leaf extract of $A$. indica, $A$. roxburghiana, $R$. elegans, $V$. negundo_and seed extract of Melia azedarach with 56.39, 49.72, $42.22,42.22$ and 44.16 per cent inhibition, respectively. Arya (2010) reported effectiveness of leaf extracts of $O$. sanctum, A. indica against post-harvest fruit rot pathogens in grapes and guava. Faria et al. (2006) observed antifungal activity of Ocimum spp. against Botryosphaeria rhodina. Ethanol extract of ripe fruits of $\mathrm{Me}$ - lia azedarach is reported to exhibit fungistatic activities against fungi like Aspergillus niger, Fusarium moniliformae, Microsporium canies and Candida albicans (Carpinella et al., 1999). Lopez-Reyes et al. (2013) observed that essential oil obtained from Ocimum basilicum was effective against brown rot (Monilinia laxa) and grey mould rot (Botrytis cinerea) pathogens in stone fruits. Onyeani et al. (2012) observed that aqueous leaf extract of Azadirachta indica and Aloe vera were equally effective in reduction of mycelial growth of Aspergillus niger. Antifungal activity of cow urine has been reported against various plant pathogens viz. Fusarium oxysporum, Rhizopus oligosporus, Alternaria helianthi and Trichoderma viride (Patil, 2007). Sathasivam et al. (2010) also reported the anti-microbial properties of cow urine and composted cow dung on clinical pathogens and phyto-pathogenic fungi, respectively.

Increased antimicrobial activity of cow urine may be due to its hydrolytic state, the presence of amino acids in urinary peptides formation of reactive compounds like formaldehyde, sulffinol, ketones and amines during long term storage, heating and photo activation (Minocheherhomji and Vyas, 2014).Cow's urine is also quite effective because it does not contain a toxic effluent as $95 \%$ of its content being water, $2.5 \%$ urea and the remaining $2.5 \%$, a mixture of minerals, salts, hormones and enzymes. The biochemical estimation of cow urine has shown that it contains sodium, nitrogen, sulphur, iron, silicon, chlorine, magnesium, calcium salts, phosphate, lactose, carbolic acid and enzymes (Tomar and Raj, 2015).

It was evident from the data that all these fungicides significantly inhibited the mycelial growth of the white rot pathogen in comparison to control (Table 3). Difenoconazole was found most effective and significantly superior among all the treatments with 75.01 per cent average inhibition in mycelial growth of the white rot pathogen followed by tebuconazole 71.68 per cent. BF1, BF2 and Fungicide significantly inhibited the mycelial growth of the white rot pathogen in comparison to control. Kim and Uhm (2002) also reported that white rot of apple can be effectively controlled by application of difenoconazole. Pitt et al. (2010) reported the efficacy of tebuconazole under in vitro conditions against mycelial growth of black rot pathogen ( $B$. obtusa). Difenoconazole has been reported to effectively check the conidial 
germination and radial mycelial growth of Diplodia spp. and B. obtusa under in vitro conditions (Auger et al., 2004 and Morales et al., 2012). In the present study, both the botanical formulations i.e. made with water (BF1) or cow urine (BF2) were found effective in inhibiting the mycelial growth of white rot pathogen $(B$. dothidea). BF2 was found more effective than BF1. Botanical Formulation 2 (BF2) inhibited the overall mycelial growth of the test pathogen by 48.38 per cent in comparison to Botanical Formulation 1 (BF1) with 45.34 per cent overall mycelial growth inhibition. Further, BF2 inhibited mycelial growth by 72.70 in comparison to 66.37 per cent mycelial inhibition in BF1 at 100 $\%$ concentration (Table 4). Gautam (2011) reported that bio-formulation which has been made from leaves or seeds of plant species like Bougainvillea glabra, Eucalyptus globules, Mentha piperita, Melia azedarach, Roylea elegans, Dodonaea viscosa and cow urine was effective against five major post-harvest rots in apple viz., blue mould rot (Penicillium expansum), bitter rot (Glomerella cingulata), brown rot (Monilinia fructigena), pink mould rot (Trichothecium roseum) and whisker's rot (Rhizopus stolonifer). Raj and Tomar (2013) also reported the efficacy of aqueous and cow urine based plant extracts. Cow urine based bioformulation was reported to be more effective in inhibiting mycelial growth of different post-harvest pathogens of apple. Similarly, cow urine based botanical formulation has been reported more effective against grey rot disease of strawberry (Raj and Sharma, 2013).Thus, cow urine based botanical formulation (BF2) was found very effective in limiting the mycelial growth of $B$. dothidea. In conclusion, cow urine based botanical formulations can be used for its novel, less expensive and eco-friendly nature for management of white rot of apple.

\section{Conclusion}

Among different treatments, cow urine based botanical formulations (BF2) inhibited mycelial growth of white rot pathogen by $72.70 \%$ at its $100 \%$ concentration in comparison to control. Thus, there is need for further research in this regard, as cow urine can be easily available, cheap, unharmful potential substitute for chemicals especially in the edible products. Protection of stored apples from post-harvest diseases by use of chemicals lead to residual toxicity in human body. Therefore, aqueous and cowurine based botanical formulation can be used as potential source of inexpensive and efficient source of crop protection from number of post-harvest diseases.

\section{ACKNOWLEDGEMENTS}

The authors are thankful to Head, Department of Plant Pathology, Dr. Y. S. Parmar University of Horticulture and Forestry, Nauni, Solan-173230 (HP), for providing necessary facilities during the experiment.

\section{REFERENCES}

Akhter, N., Begum, M.F., Alam, S. and Alam M.S. (2006). Inhibitory effect of different plant extracts, cow dung and cow urine on conidial germination of Bipolaris sorokiniana. J Bio-sci., 14: 87-92.

Arya, A. (2010). Recent advances in the management of fungal pathogens of fruit crops. In: Management of Fungal Plant Pathogens, Arya A. and Perello A. E. (eds.), Commonwealth Agricultural Bureaux International,Wallingford,UK. pp.1-25.

Auger, J., Esterio, M., Ricke, G. and Perez, I. (2004). Black dead arm and basal canker of Vitisvinifera cv. Red Globe caused by Botryosphaeria obtusa in Chile. Plant Dis., 88: 1286.

Basak, A.B., Lee, M.W. and Lee, T. S. (2002). Inhibitive activity of cow urine and cow dung against Sclerotinia sclerotiorum of cucumber. Mycobiology., 30(3): 175179.

Carpinella, M. C., Herrero, G. G., Alonso, R. A. and Palacios, S. M. (1999). Antifungal activity of Melia azedarach fruit extract. Fitoterapia., 70: 296-298.

Chauhan, R.S. (2004). Panchagavya Therapy (Cow pathy): current status and future directions. The Indian Cow., 1: 3-7.

Falck, R. (1907). Wachtumgesetze, wachstumlotaktorchund temperature wertderholzersterenden. Myceture, 32:3839.

Faria, T. J., Ferreira, R. S., Yassumoto, L., Desouza,J R P., Ishikawa, N. K. and Barbosa, A. D. (2006). Antifungal activity of essential oil isolated from Ocimum gratissimum L. (eugenol chemotype) against phytopathogenic fungi. Braz Arch Bio and Technol., 49(6): 867-871.

Fulkerson, J. F.(1960). Botryosphaeria ribis and its relation to rot of apple. Phytopathology, 50: 394-398.

Gautam, H. R.( 2011). Eco-friendly bio-formulation for fruit production. Science Reporter., 48 (6): 17.

Jones A L and Aldwinckle H S (eds.). 1990. Compendium of Apple and Pear Diseases. American Phytopathological Society, Press, St. Paul, Minnesota, USA. 100 pp.

Kaul, J. L. (1979). Studies on important postharvest diseases of apple caused by fungi and their control, Ph.D. Thesis, Himachal Pradesh Krishi Vishvavidyalaya, Solan (HP), India $214 \mathrm{p}$.

Kim, D. H. and Uhm, J. Y. (2002). Effect of application timing of ergosterol biosynthesis-inhibiting fungicides on the suppression of disease and latent infection of apple white rot caused by Botryosphaeria dothidea. $J$. Gen. Plant Pathol., 68(3): 237-245.

Konstantinou, S., Karaoglanidis, G. S., Bardas, G. A., Minas, I. S., Doukas, E. and Markoglou, A. N. (2011). Postharvest fruit rots of apple in Greece: pathogen incidence and relationships between fruit quality parameters, cultivar susceptibility and patulin production. Plant Dis., 95: 666-672.

Lopez-Reyes, J. G., Spadaro, D., Prelle, A., Garibaldi, A. and Gullino M. L. (2013). Efficacy of plant essential oils on postharvest control of rots caused by fungi on different stone fruits in vivo. J.Food Prot., 76 (4): 631639.

Minocheherhomji, F. P. and Vyas, B.M. (2014). Study of the antimicrobial activity of cow urine and medicinal plant extracts on pathogenic Human microbial strains. IJAPBC., 3(4): 836-840. 
Morales, A., Latorre, B. A., Piontelli, E. and Besoain, X. (2012). Botryosphaeriaceae species affecting table grape vineyards in Chile and cultivar susceptibility. Cienc. Investig. Agrar., 39 (3): 445-458.

Murugan, A. M., Shanthi, S., Arunachalam, C., Sivakumar, N., Elamathy, S. and Rajapandian, K. (2012). Study on cow urine and Pongamiapinnata Linn seed in farmyard: a natural, cost effective, ecofriendly remedy to bacterial leaf blight (BLB) of paddy. Afr. J. Biotechnol., 11(40): 9591-9598.

NHB, Gurgaon (2014). Indian Horticulture Database. National Horticulture Board, Gurgaon, Ministry of Agriculture, Government of India, 286pp.

Onyeani, C. A., Osunlaja, S. O., Oworu, O. O. and Joda, A. O. (2012). Evaluation of effect of aqueous plant extract in the control of storage fungi. $I J S T R$., 1(6): 76-79.

Patil, R. H. S. (2007). Antifungal potency of cow urine. Bioscience., 1: 4-5.

Pitt, W. M., Sosnowski, M. R., Taylor, A., Juan, H. R., Quirk, L. , Hackett, S., Somers, A., Steel, C. C. and Savocchia, S. (2010). Management of Botryosphaeria canker of grapevines. Australian Viticulture Practical Vineyard Management., 4(2): 52- 56.
Putterill, V. A. (1919). A new apple tree canker. S Afr J Sci., 16: $258-271$.

Raj, H. and Sharma, R. L. (2013). Bioefficacy of aqueousand cow urine based bioformulations against grey mould of strawberry. J Mycol Plant Pathol., 43(3): 319322.

Raj, H. and Tomar, M. (2013). Use of aqueous and cow urine based plant extracts against post-harvest diseases of apple. J Mycol Plant Pathol., 43 (2): 246-249.

Sathasivam, A., Muthuselvam, M. and Rajendran, R. (2010). Antimicrobial activities of cow urine distillate against some clinical pathogens. GJ P., 4(1): 41-44.

Snowden, A. L. (1990). A color atlas of post-harvest diseases and disorders of fruits and vegetables. Vol. 1. General introduction and fruits. CRC Press, Boca Raton, FL, $302 \mathrm{pp}$.

Tomar, M. and Raj, H. (2015) Use of native local bio resources and cow urine for the effective management of post-harvest diseases of apples in northwest himalayan states of India. Journal of Plant Pathology and Microbiology., l 6: 316 .

Vincent, J. M. (1947). Distortion of fungal hypae in the presence of certain inhibitors. Nature 150: 850 . 